\title{
CUTA wt Allele
}

National Cancer Institute

\section{Source}

National Cancer Institute. CUTA wt Allele. NCI Thesaurus. Code C114654.

Human CUT A wild-type allele is located in the vicinity of $6 \mathrm{p} 21.32$ and is approximately 2 $\mathrm{kb}$ in length. This allele, which encodes protein CutA, may be involved in acetylcholinesterase localization. 